\title{
Specific Binding of Vasoactive Intestinal Peptide Receptor in Cephalic and Caudal Lobes of Anterior Pituitary of Incubating and Laying Hens and Roosters
}

\author{
Sylvia Mae T. Gonzales ${ }^{1}$, Mitsuo Kawashima ${ }^{2}$, Michiharu Kamiyoshi', \\ Takehito Kuwayama, ${ }^{1}$ Katuhide Tanaka ${ }^{1}$ and Kenji Ichinoe ${ }^{1}$ \\ ${ }^{1}$ Department of Zootechnical Science, Tokyo University of Agriculture, Tokyo 156 \\ ${ }^{2}$ Faculty of Agriculture, Gifu University, Gifu 501-11
}

\begin{abstract}
Specific bindings to radioiodinated chicken vasoactive intestinal peptide (VIP) were measured in the membrane fraction of the cephalic and the caudal lobes of anterior pituitary of Japanese native breed of chicken, Gifujidori. The specific binding per mg protein in the cephalic lobe was much greater in incubating hens than in laying hens and less in roosters than in the hens. In the caudal lobe, however, it was not different between the incubating and laying hens and between the hens and the roosters. The greater binding in the cephalic lobe in the incubating hens may be concerned in the incubation behavior through the stimulatory action of VIP for prolactin secretion.
\end{abstract}

(Jpn. Poult. Sci., $31:$ 300-304, 1994)

Key words : VIP receptor, anterior pituitary, cephalic lobe, caudal lobe, Gifujidori

\section{Introduction}

Vasoactive intestinal peptide (VIP) is known to stimulate the release of prolactin from the anterior pituitary of chickens (Macnamee et al., 1986 ; Proudman and Opel, 1988). The presence of receptors for vasoactive intestinal peptide (VIP) in the anterior pituitary of chickens was recently found (Gonzales et al., in press) as already reported in turkeys (Rozenboim and El Halawani, 1993) and rats (Vijayan et al., 1979). Prolactin induces incubation behavior (RIDDLE et al., 1935) in a certain breed of chickens possessing genetical broodiness (SAEKI and TANABE, 1955). The anterior pituitary of birds is divided into two histologically distinct regions named "cephalic" and "caudal" lobes (RAHN and PAINTER, 1941). Although immunocytochemical studies revealed the presence of prolactin secreting cells mainly in the cephalic lobe and not in the caudal lobe of the anterior pituitary of the quail (MIKAMI and YAMADA, 1984), biological (NAKAJO and TANAKA, 1956) or immunoreactive (MACNAMEE et al., 1986) prolactin has been found in both lobes of the anterior pituitary of chickens. The prolactin content of the pituitary is greater in the cephalic lobe than in the caudal lobe in laying hens (NAKAJO and TANAKA, 1956) and as a whole is greater in incubating hens than in laying hens (SAEKI and TANABE, 1955). The present experiments were performed to demonstrate whether the amount of specific binding of VIP receptor between the cephalic and caudal lobes

Received Nov. 30, 1993 
of the anterior pituitary differs between incubating and laying hens, and between hens and roosters.

\section{Materials and Methods}

Hens (18 months of age ; $0.68-1.20 \mathrm{~kg} \mathrm{BW}$ ) and roosters (18 months of age; $1.20-1.60$ $\mathrm{kg} \mathrm{BW}$ ) of Japanese native breed of chicken, "Gifujidori", were used. The birds were obtained from one flock of birds kept in floor pens under 14-h (5:00-19:00) light/day with feed and water provided ad libitum. Hens laying 3-6 eggs in a sequence (clutch) with a 1-day pause between sequences for more than 2 weeks before experiment were used as laying hens. Broody (incubating) hens were also used on the day when recognized their incubation behavior, i.e. during the period of 1 to 2 weeks of incubation. The hens were regarded as being incubating when sitting on the nest at least 3 times per day for at least 3 consecutive days and offered extreme resistance to being dislodged from the nest and incubated eggs. All birds (30 birds in each group) killed by decapitation at $10: 00 \mathrm{~h}$, and the anterior pituitary was excised and divided into cephalic and caudal lobes. The lobes were weighed and pooled in each group.

Membrane fractions were prepared using the method of W ANKE and RORSTAD (1990) with slight modifications. The cephalic and caudal lobes were homogenized in $25 \mathrm{vol} /$ wt TEM buffer $\left(25 \mathrm{mmol} / l\right.$ Tris- $\mathrm{HCl}, 2 \mathrm{mmol} / l$ EDTA, $2 \mathrm{mmol} / l \mathrm{MgCl}_{2}, \mathrm{pH} 7.4$ ) in a Potter-Elvehjem glass teflon homogenizer. The homogenate was centrifuged at $700 \times$ $\mathrm{g}$ for $10 \mathrm{~min}$, and the supernatant was obtained. The precipitate was homogenized and recentrifuged. The supernatants were collected and centrifuged at $13,000 \times \mathrm{g}$ for 30 min. The resultant sediments were washed twice with TS buffer $(25 \mathrm{mmol} / l \mathrm{Tris}-\mathrm{HCl}$, $0.25 \mathrm{~mol} / l$ Sucrose, $\mathrm{pH}$ 7.4). The washed pellet was suspended in $2 \mathrm{vol} / \mathrm{wt}$ TS buffer and used as a membrane fraction. The protein concentration of the fraction was measured by the method of Lowry et al. (1951) using BSA as a standard.

The chicken VIP (cVIP) was labeled with $\mathrm{Na}{ }^{125} \mathrm{I}$ using the iodogen method (KAWASHIMA et al., 1992 ; TAKAHASHI et al., 1992) and chromatographed on a $1 \times 100 \mathrm{~cm}$ column of Sephadex G-25 (super fine type) eluted with 0.1\% BSA-0.1 M acetic acid. Two clearly separated radioactive peaks prior to free ${ }^{125} \mathrm{I}$ peak were obtained. The first peak bound well to the membrane fraction, and the percentage of nonspecific binding to total binding was less than $20 \%$, but the second peak bound poorly. The specific activity of ${ }^{125} \mathrm{I}-\mathrm{cVIP}$, expressed as monoiodo-cVIP, was calculated to be $480-670 \mathrm{Ci}$ / mmol assuming a complete recovery of the peptide. All experiments performed within 40 days after radioiodination.

The specific binding of ${ }^{125}$ I-cVIP was measured by the use of the method of W ANKE and RoRsTAD (1990) with modifications. The diluent used was TMB buffer (25 mmol/ $l$ Tris- $\mathrm{HCl}, 2 \mathrm{mmol} / l \mathrm{MgCl}_{2}, 0.2 \mathrm{mmol} / l$ bacitracin, $\mathrm{pH}$ 7.4) containing $0.1 \% \mathrm{BSA}$ and 1 $\mathrm{mmol} / l \mathrm{PMSF}$. Aliquots of the membrane fraction (30 $\mu \mathrm{g}$ protein/tube ; two tubes per assay) were incubated at $30^{\circ} \mathrm{C}$ for $1 \mathrm{~h}$ with ${ }^{125} \mathrm{I}-\mathrm{cVIP}$ in the absence (total binding) or presence (nonspecific binding) of unlabeled cVIP in a total volume of $200 \mu l$. After the incubation, $2 \mathrm{~m} l$ of ice-cold TMB buffer was added. Bound and free radioligands were separated by rapid filtration under vacuum through glass microfiber filters (GF/B type 
; Whatman, Clifton, NJ, USA) that were presoaked overnight in $0.5 \%$ polyethylenimine to reduce the value of background. The fllters were washed twice with $2 \mathrm{~m} l \mathrm{TMB}$ buffer and measured for the radioactivity by a gamma counter (Cobra Model B5002 ; Packard Instrument Co., Meriden, CT, USA) with the counting efficiency of $65-82 \%$. Specific binding was obtained by subtracting the nonspecific binding from the total binding, and expressed as moles per mg protein.

Newman Keuls' Test (SNEDECOR, 1956) was used to assess the significance of difference between means.

\section{Results and Discussion}

Table 1 shows the results. The specific binding of VIP receptor in the anterior pituitary of incubating hens was found to be greater in the cephalic lobe than in the caudal lobe, but not in the pituitaries of laying hens and roosters. The specific binding in the cephalic lobe of the incubating hens was also greater than that in the same lobe of the laying hens. Since VIP stimulates the secretion of prolactin (SHARP et al., 1989; El HalawANi et al., 1990 ; TALBOT et al., 1991), the greater binding in the cephalic lobe in the incubating hens may be concerned in the incubation behavior of the hens expressed by an increased secretion of prolactin (SHARP et al., 1979 ; BEDRAK et al., 1981 ; LEA et al., 1981, 1982) by the action of VIP through its receptor bindings. The specific binding in the cephalic lobe of the laying hens was greater than that in the same lobe of the roosters. If the blood level of prolactin were more concerned to the secretion from the cephalic lobe than from the caudal lobe, the difference in the specific binding of the cephalic lobe between the incubating and laying hens and between the hens and the roosters would be explainable by the difference in the blood level of prolactin which is known to be higher in incubating hens than in laying hens and lower in

Table 1. Specific ${ }^{125} \mathrm{I}-\mathrm{cVIP}$ binding of membrane fractions from cephalic and caudal lobes of the anterior pituitary of incubating hens ${ }^{1}$, laying hens ${ }^{1}$ and roosters ${ }^{1}$.

\begin{tabular}{lcc}
\hline \hline \multicolumn{1}{c}{ Bird } & Cephalic Lobe & Caudal Lobe \\
\cline { 2 - 3 } & \multicolumn{1}{c}{$\mathrm{fmol} / \mathrm{mg}$ protein ${ }^{2}$} \\
Incubating Hens & $114.8 \pm 8.2^{\text {\#at\# }}$ & $42.6 \pm 3.8^{\text {\#肘 }}$ \\
Laying Hens & $30.3 \pm 3.4^{\mathrm{b}}$ & $39.8 \pm 4.3^{\mathrm{b}}$ \\
Roosters & $9.3 \pm 1.2^{\mathrm{c}}$ & $22.8 \pm 2.6^{\mathrm{bc}}$ \\
\hline
\end{tabular}

1. Japanese native breed of chicken, Gifujidori

2. Membrane fractions ( $30 \mu \mathrm{g}$ protein/tube) were incubated at $30^{\circ} \mathrm{C}$ for $2 \mathrm{~h}$ with $0.7 \mathrm{nM}{ }^{125} \mathrm{I}-\mathrm{cVIP}$ in the absence or presence of a 100 -fold molar excess of unlabeled cVIP, and the specific ${ }^{125}$ I-cVIP binding was measured.

* Mean \pm SEM of four determinations.

\# Meanswith a different letter are significantly different between bird groups and between lobes at $1 \%$ level by Newman Keuls' Test 
roosters than in hens incubating or laying (SHARP et al., 1979 ; GonZALES et al., unpublished).

\section{Acknowledgments}

The authors wish to express their appreciation to Kazuhiro MATsUI and Akiko HIRANo for technical assistance. This work was supported by the Grant-in-Aid from the Ministry of Education, Science and Culture (No. 03454097).

\section{References}

BedRak. E., S. Harvey and A. Chadwick(1981) Concentrations of pituitary, gonadal and adrenal hormones in serum of laying and broody White Rock hens (Gallus domesticus). Journal of Endocrinology, 89 : 197-204.

El Halawani, M.E., J.L. Silsby and L.J. Mauro (1990) Vasoactive intestinal peptide is a hypothalamic prolactin-releasing neuropeptide in the turkey (Meleagris gallopavo). General and Comparative Endocrinology, $78: 66-73$.

GonZales, S.M., M. Kawashima, M.KamiYoshi, K.TAnaKa and K.Ichinoe (1994) Vasoactive intestinal polypeptide receptors in the anterior pituitary of female chickens. Journal of Reproduction and Development (in press).

KawAshima, M., M. KamiYoshi and K. TANAKA (1992) Luteinizing hormone-releasing hormone receptor bindings of the hen pituitary : Difference between laying and nonlaying hens, effects of ovarian steroid hormones in vivo, and changes during an ovulatory cycle. Poultry Science, $71: 1079-1086$.

LEa, R.W., A.S.M. Dods, P.J. Sharp and A. Chadwick (1981) The possible role of prolactin in the regulation of nesting behaviour and the secretion of luteinizing hormone in broody bantams. Journal of Endocrinology, $91: 89-97$.

LEA, R.W., P.J. Sharp and A. Chadwick (1982) Daily variations in the concentrations of plasma prolactin in broody bantams. General and Comparative Endocrinology, $48: 275-284$.

Lowry, O.H., N.J. Rosebrough, A.L. FarR and R.J. Randall (1951) Protein measurement with the folin phenol reagent. Journal of Biological Chemistry, 193 : 265-275.

Macnamee, M.C., P.J. Sharp, R.W. Lea, R.J. Sterling and S. Harvey (1986) Evidence that vasoactive intestinal polypeptide is a physiological releasing factor in the bantam hen. General and Comparative Endocrinology, $62:$ :70-478.

MiKami, S. and S. YAMADA (1984) Immunohistochemistry of the hypothalamic neuropeptides and anterior pituitary cells in the Japanese quail. Journal of Experimental Zoology, 232 : 405-417.

NaKAJO, S. and K. TANAKa (1956) Prolactin potency of the cephalic and the caudal lobes of the anterior pituitary in relation to broodiness in the domestic fowl. Poultry Science, 35 : 990-994.

PROUdMAN, J. and H. OPEL (1988) Stimulation of prolactin secretion from turkey anterior pituitary cells in culture. Proceedings of the Society for Experimental Biology and Medicine, $187: 448$ -454 .

RAHN, H. and B.T. PainTER (1941) A Comparative histology of the bird pituitary. Anatomical Record, $79:$ : 297-308.

Riddle, O., R.W. Bates and E.R. LAHR (1935) Prolactin induces broodiness in fowl. American Journal of Physiology, $111: 352-360$.

Rozenboim, I. and M.E. El Halawani (1993) Characterization of vasoactive intestinal peptide pituitary membrane receptors in turkey hens during different stages of reproduction. Biology of Reproduction, $48: 1129-1134$.

SAEKI, Y. and Y. TANABE (1955) Changes in prolactin content of fowl pituitary during broody periods and some experiments on the induction of broodiness. Poultry Science, 34 : 909-919.

Sharp, P.J., C.G. Scanes, J.B. Williams, S. Harvey and A. Chadwick (1979) Variations in concentration of prolactin, luteinizing hormone, and progesterone in the plasma of broody bantams (Gallus domesticus). Journal of Endocrinology, 80 : 51-57.

Sharp, P.J., R.J. Sterling, R.T. Talbot and N.S. Huskisson (1989) The role of hypothalamic 
vasoactive intestinal polypeptide in the maintenance of prolactin secretion in incubating bantam hens:observations using passive immunization, radioimmunoassay and immunohistochemistry. Journal of Endocrinology, $122: 5-13$.

SNEDECOR, G.W. (1956) Two or more random samples of measurement data. Analysis of variance In : SNEDECOR, G.W. (ed) Statistical Methods, 5 th ed. Iowa State University Press, Ames, Iowa, 237-290.

TaKahashi, T., M. Kawashima, M. KamiYoshi and K. TanaKa (1992) Arginine vasotocin binding component in the uterus (shell gland) of the chicken. Acta Endocrinologica, $127: 179-184$.

Talbot, R.T., M.C. Hanks, R.J. Sterling, H.M. Sang and P.J. Sharp (1991) Pituitary prolactin messenger ribonucleic acid levels in incubating and laying hens: Effects of manipulating plasma levels of vasoactive intestinal polypeptide. Endocrinology, $129: 496-502$.

ViJayan, E., W.K. SAmson, S.I. SAID and S.M. MCCANN (1979) Vasoactive intestinal peptide: Evidence for a hypothalamic site of action to release growth hormone, luteinizing hormone and prolactin in conscious ovariectomized rat. Endocrinology, 104:53-57.

WANKE, I.E. and O.P. RORSTAD (1990) Developmental and lactational changes in the rat anterior pituitary VIP receptor. Peptides, $11: 667-672$.

\section{抱卵鶏，産卵鶏及び雄鶏の下垂体前葉の前部腺体並びに 後部腺体における血管作用性腸ペプチド・ レセプターの特異的結合量 \\ シルビア M. T. ゴンザレス・川島光夫* ・上吉道治 * 桑山岳人・ 田中克英・一戸健司 \\ 東京農業大学畜産学科, 東京都 156 \\ *岐阜大学農学部, 岐皁市 501-11}

岐阜地鶏の抱卵鶏, 産卵䳕及び雄鶏の下垂体前葉前部 腺体並びに後部腺体の細胞膜画分について放射性ヨード 標識ニワトリ血管作用性腸ペプチド（VIP）に対する特 異的結合量を测定した結果, 蛋白質 $1 \mathrm{mg}$ 当たりの特異 的結合量は抱卵彩においては前部腺体の方が後部腺体よ りも多かったが, 産卵鶏や雄鶏では両腺体間に差異は認 められなかった。前部腺体における特異的結合量は抱卵 鶏が最も多く, 次いで産卵鶏であり, 雄鶏は最少であっ
た。抱卵鶏の前部腺体の特異的結合量が産卵鷂や雄鶏よ りあ多いことは, 下垂体前葉におけるVIPのレセプ ターを介するプロラクチン分泌促進作用にもとずく抱卵 行動と関係しているすのであろう。

（家离会誌, $31: 300-304,1994)$ キーワード : VIP レセプター, 下垂体前葉, 前部腺体, 後部腺体, 岐阜地鵎 